\title{
Adoption of Fodder Production and Conservation Technology in Bundelkhand, Uttar Pradesh, India
}

\author{
Sarju Narain ${ }^{1 *}$, Shobhana Gupta ${ }^{1 \#}$ and Sudhir K. Rawat ${ }^{2}$ \\ ${ }^{1}$ Dept of Agril. Extension, Brahmanand PG College, Rath, Hamirpur, U.P. (210 301), India \\ ${ }^{1 \# P r e s e n t l y ~ D i r e c t o r a t e ~ o f ~ E x t e n s i o n ~ S e r v i c e s, ~ R a j m a t a ~ V i j a y a r a j e ~ S c i n d i a ~ K r i s h i ~ V i s h w a ~ V i d y a l a y a, ~}$ \\ Gwalior, M.P. (474 005), India \\ ${ }^{2}$ Krishi Vigyan Kendra, Mahoba, CSAUAT, Kanpur, U.P. (210 427), India
}

\section{Article History}

Manuscript No. AR1549a

Received in $4^{\text {th }}$ March, 2016

Received in revised form $28^{\text {th }}$ July, 2016

Accepted in final form $30^{\text {th }}$ July, 2016

\section{Correspondence to}

"E-mail: drsarju75@gmail.com

\section{Keywords}

Bundelkhand, fodder production, conservation, knowledge, adoption, constraints

\begin{abstract}
Livestock keeping provides an assured income to the farmers of Bundelkhand region as it is more reliable than crop husbandry. But these days the farmers are giving up rearing the livestock due to shortage of fodder and shrinking areas of fodder cultivation. Purchasing the fodder becomes a costly affair for the farmers and so over dependence on post-harvest residues of crops and grasses as well as traditional grazing practice increases. The traditional grazing practice, when becomes uncontrolled converts into Annapratha in some areas of this region which loses many acreage of crops per year. The researcher has tried to see ground realities of fodder production and conservation in Bundelkhand region of Uttar Pradesh with this study conducted in five districts of Bundelkhand region of Uttar Pradesh (India) in 2014-15 involving 200 respondents. The item "Names of leguminous and non-leguminous roughages" was ranked first followed by "Fodder requirement and cropping scheme preparation based on number of animals", and "Importance of different roughages for animal health" ranked third. The highest adoption was found for the practices for which respondents had highest knowledge in terms of knowledge of the respondents. The highest constraints were related to "Technology transfer" followed by "Farmers purchasing capacity". The study revealed that by addressing the issues of knowledge, adoption and constraints, the fodder production in the region can be enhanced thus providing another assured source of income.
\end{abstract}

\section{Introduction}

India is blessed with highest livestock population comprising of 185 million cattle, 97 million buffaloes, 61 million sheep, 124 million goats and more than 0.7 million other livestock. Looking towards the animal husbandry practices throughout India, it is clear that there is a wide gap between the requirement and availability of either roughage or concentrates (Sampath and Samanta, 2010). In India, over $70 \%$ of milk is produced by semi-medium, small, marginal and landless farmers who cannot feed livestock properly. A large scale migration and roaming of livestock population in the search of feed and fodder is very common. Low productivity, under nourishment, infertility and delayed conception, etc. are very common in livestock caused due to malnutrition-a result of fodder scarcity.

Increasing human population is reducing the common property resources for animal grazing therefore, grazing land is disappearing (Manjunath, 2011) which is the prime constraints perceived by the dairy farmers in several parts of the country including Bundelkhand region of Uttar Pradesh. This region has hot climate, undulating topography, residual and low depth of soil, poor availability of irrigation water and fodder. Farmers of this semi-arid tract have been generally practicing monocropping with insufficient acreage of fodder for their animals. Adverse climatic conditions especially drought resulting in widespread crop failure leads to acute shortage of feed and fodder adversely affecting the livestock health and production.

Due to shortage of fodder and shrinking areas of fodder cultivation many farmers in this region is giving up rearing the livestock. The scarcity of feed and fodder increases the chances of purchased commodity but all livestock keepers cannot afford. They only depend upon post-harvest residues of crops and grasses as well as traditional grazing practice. The traditional grazing practice, when becomes uncontrolled converts into Annapratha in some areas of this region which loses many acreage of crops year ${ }^{-1}$. In this background, a study 
was conducted on "ground realities of fodder production and conservation in Bundelkhand region of Uttar Pradesh".

\section{Materials and Methods}

Out of seven districts in Bundelkhand region, five namely, Hamirpur, Jalaun, Jhansi, Lalitpur and Mahoba, were purposively selected for the study during 2014-15. From each district, two blocks and from each block one village was selected randomly. Total 10 blocks and 10 villages were selected form five districts (Table 1). From each village 20 fodder growing farmers having animals were identified and randomly selected as respondents. Hence, total 200 respondents were directly interviewed and data collected on pre-determined schedule. The collected data were processed, tabulated and analyzed.

A 3-point rating scale was used with categories "unknown" (score 1), "partially known" (score 2) and "fully known" (score 3) to know knowledge level and "poor", "fair" and "good" to know adoption level related to fodder production and conservation. The mean value of each aspect was also calculated by multiplication of allotted numerical value with number of respondents and divided by total number of respondents. Then ranks were given for achieved values. The highest rank was given for higher values. In this study, constraints were operationalized as certain obstacles or problems experienced by the respondents related to fodder production and conservation. Constraints were measured in frequency and percentage and ranked accordingly.

\section{Results and Discussion}

\subsection{Knowledge level}

Knowledge level was studied based on 10 parameters, viz. name of leguminous and non-leguminous fodders, varieties of fodders grown, fodder requirement and cropping scheme preparation based on number of animals, seed rate and sowing time of different fodders, importance of different fodders for animal health, harvesting time and stage of green fodder, postharvest management of fodder, silage making (importance, suitable corps and making process), hay making (importance, suitable crops and making process) and value addition in straw with 3-4\% urea $+1 \%$ mineral mixture +50 liter of water in 100 $\mathrm{kg}$ dry fodder.

Table 2 reveals that respondents had highest knowledge about the name of leguminous and non-leguminous roughage for animals, i.e. rank-I. Rank-II was given to fodder requirement and cropping scheme preparation based on number of animals with mean value 2.02 followed by rank-III to importance of different roughages for animal health with mean value 1.89 . The lowest knowledge level, i.e. rank-X with mean value 1 was found about the item number 10 , i.e. value addition in dry fodder.

After rank-III parameter, harvesting time and stage of green fodder, post-harvest management of fodder/grass, seed rate and sowing time of different roughage, varieties of roughages grown, hay making, silage making were ranked IV, V, VI, VII, VIII and IX, respectively according to their mean score value. The findings are supported by the works of Rajput et al. (2012) in Chattarpur region of Bundelkhand where he found that highest training needs of farmers were regarding health of animals (74.38\%) followed by fodder issues (73.79\%). The areas where the farmers knowledge level was low needs training.

\subsection{Adoption level}

Table 3 reveals the adoption level among respondents regarding adoption pattern of fodder production and conservation. The highest adoption was found about the items for which highest knowledge was there. The lowest adoption was also there for the items for which there was the lowest knowledge level.

It means knowledge was essential for adoption of suitable fodder/plant/grass species for scientific harvest and storage (Singh and Sharma, 2010). The availability of suitable plant type was found deciding factor to accelerate the adoption. Because the fodder was a subsistence crop, under micro situations, the priority of farmer was different and did not necessarily match with the technology developed. Increased knowledge and awareness level was generally considered prerequisites for adoption of new practices and technology (Rogers, 1995; Kumar, 2009). The constraints for adoption are to be addressed to improve the situation.

\subsection{Constraints in fodder production}

It is evident from Table 4 that constraints related to fodder production and conservation technology were divided into

\begin{tabular}{|c|c|c|c|c|}
\hline \multicolumn{5}{|c|}{ Table 1: Blocks and villages studied } \\
\hline $\begin{array}{l}\text { Sl. } \\
\text { No. }\end{array}$ & $\begin{array}{c}\text { District } \\
\text { (selected } \\
\text { purposively) }\end{array}$ & $\begin{array}{c}\text { Block } \\
\text { (selected } \\
\text { randomly) }\end{array}$ & $\begin{array}{c}\text { Village } \\
\text { (selected } \\
\text { randomly) }\end{array}$ & $\begin{array}{c}\text { Sample (N: } \\
\text { (selected } \\
\text { randomly) }\end{array}$ \\
\hline 1. & Hamirpur & $\begin{array}{l}\text { Sarila, } \\
\text { Rath }\end{array}$ & $\begin{array}{l}\text { Sarila, } \\
\text { Saidpur }\end{array}$ & 40 \\
\hline 2. & Jalaun & $\begin{array}{l}\text { Dakor, } \\
\text { Kadaura }\end{array}$ & $\begin{array}{l}\text { Mohana, } \\
\text { Usargaon }\end{array}$ & 40 \\
\hline 3. & Jhansi & $\begin{array}{l}\text { Maurani- } \\
\text { pur, Month }\end{array}$ & $\begin{array}{l}\text { Churai, } \\
\text { Paharpur }\end{array}$ & 40 \\
\hline 4. & Lalitpur & $\begin{array}{l}\text { Jakhaura, } \\
\text { Tal Behat }\end{array}$ & $\begin{array}{l}\text { Jijiyawan, } \\
\text { Bamhaurisar }\end{array}$ & 40 \\
\hline \multirow[t]{2}{*}{5.} & Mahoba & $\begin{array}{l}\text { Panwari, } \\
\text { Charkhari }\end{array}$ & $\begin{array}{l}\text { Mahuwa, } \\
\text { Supa }\end{array}$ & 40 \\
\hline & Total & 10 & 10 & 200 \\
\hline
\end{tabular}




\begin{tabular}{|c|c|c|c|c|c|c|c|c|c|c|c|c|}
\hline \multirow{3}{*}{$\begin{array}{l}\text { Sl. } \\
\text { No. }\end{array}$} & \multirow{3}{*}{ Item of knowledge } & \multicolumn{11}{|c|}{ Knowledge level } \\
\hline & & \multicolumn{3}{|c|}{ Unknown } & \multicolumn{3}{|c|}{ Partially known } & \multicolumn{3}{|c|}{ Fully known } & \multicolumn{2}{|c|}{ Average } \\
\hline & & $\mathrm{F}$ & $\%$ & Rank & $\mathrm{F}$ & $\%$ & Rank & $\mathrm{F}$ & $\%$ & Rank & value & $\begin{array}{l}\text { Final } \\
\text { rank }\end{array}$ \\
\hline 1. & $\begin{array}{l}\text { Name of leguminous and non-leguminous } \\
\text { fodder }\end{array}$ & 44 & $\begin{array}{c}22 \\
(0.22)\end{array}$ & 9 & 94 & $\begin{array}{c}47 \\
(0.94)\end{array}$ & 2 & 62 & $\begin{array}{c}31 \\
(0.93\end{array}$ & 1 & 2.09 & 1 \\
\hline 2. & Varieties grown & 174 & $\begin{array}{c}87 \\
(0.87)\end{array}$ & 4 & 22 & $\begin{array}{c}11 \\
(0.22)\end{array}$ & 7 & 4 & $\begin{array}{c}2 \\
(0.06)\end{array}$ & 8 & 1.15 & 7 \\
\hline 3. & $\begin{array}{l}\text { Fodder requirement and cropping scheme } \\
\text { preparation based on number of animals }\end{array}$ & 40 & $\begin{array}{c}20 \\
(0.2)\end{array}$ & 10 & 115 & $\begin{array}{c}57.5 \\
(1.15)\end{array}$ & 1 & 45 & $\begin{array}{l}22.5 \\
(0.68)\end{array}$ & 3 & 2.03 & 2 \\
\hline 4. & Seed rate and sowing time & 122 & $\begin{array}{c}61 \\
(0.61)\end{array}$ & 5 & 44 & $\begin{array}{c}22 \\
(0.44)\end{array}$ & 6 & 34 & $\begin{array}{c}17 \\
(0.51)\end{array}$ & 5 & 1.56 & 6 \\
\hline 5. & Importance of fodders for animal health & 64 & $\begin{array}{c}32 \\
(0.32)\end{array}$ & 8 & 94 & $\begin{array}{c}47 \\
(0.94)\end{array}$ & 3 & 42 & $\begin{array}{c}21 \\
(0.63)\end{array}$ & 4 & 1.89 & 3 \\
\hline 6. & $\begin{array}{l}\text { Harvesting time and stages of green } \\
\text { fodder/grass }\end{array}$ & 86 & $\begin{array}{c}43 \\
(0.43)\end{array}$ & 7 & 64 & $\begin{array}{c}32 \\
(0.64)\end{array}$ & 5 & 50 & $\begin{array}{c}25 \\
(0.75)\end{array}$ & 2 & 1.82 & 4 \\
\hline 7. & Post-harvest management of fodder/grass & 94 & $\begin{array}{c}47 \\
(0.47)\end{array}$ & 6 & 74 & $\begin{array}{c}37 \\
(0.74)\end{array}$ & 4 & 32 & $\begin{array}{c}16 \\
(0.48)\end{array}$ & 6 & 1.69 & 5 \\
\hline 8. & $\begin{array}{l}\text { Silage making (importance, suitable } \\
\text { corps and making process) }\end{array}$ & 192 & $\begin{array}{c}96 \\
(0.96)\end{array}$ & 2 & 8 & $\begin{array}{c}4 \\
(0.08)\end{array}$ & 9 & 0 & $0(0)$ & 9 & 1.04 & 9 \\
\hline 9. & $\begin{array}{l}\text { Hay making (importance, suitable corps } \\
\text { and making process) }\end{array}$ & 180 & $\begin{array}{c}90 \\
(0.9)\end{array}$ & 3 & 14 & $\begin{array}{c}7 \\
(0.14)\end{array}$ & 8 & 6 & $\begin{array}{c}3 \\
(0.09)\end{array}$ & 7 & 1.13 & 8 \\
\hline 10. & $\begin{array}{l}\text { Value addition in straw with } 3-4 \% \\
\text { urea }+1 \% \text { mineral mixture }+50 \text { liter of } \\
\text { water in } 100 \mathrm{~kg} \text { dry fodder }\end{array}$ & 200 & $\begin{array}{l}100 \\
(1)\end{array}$ & 1 & 0 & $0(0)$ & 10 & 0 & $0(0)$ & 10 & 1 & 10 \\
\hline
\end{tabular}

$\mathrm{F}=$ Number of farmers agreed to that item; Figure in parenthesis shows value for an item; Highest rank was given to highest value

Table 3: Adoption of fodder production and conservation technolgy $(\mathrm{N}=200)$

\begin{tabular}{|c|c|c|c|c|c|c|c|c|c|c|c|c|}
\hline \multirow{3}{*}{$\begin{array}{l}\text { S1. } \\
\text { No. }\end{array}$} & \multirow{3}{*}{ Item of adoption } & \multicolumn{11}{|c|}{ Adoption level } \\
\hline & & \multicolumn{3}{|c|}{ Poor } & \multicolumn{3}{|c|}{ Fair } & \multicolumn{3}{|c|}{ Good } & \multicolumn{2}{|c|}{ Average } \\
\hline & & $\mathrm{F}$ & $\%$ & Rank & $\mathrm{F}$ & $\%$ & Rank & $\mathrm{F}$ & $\%$ & Rank & Value & Rank \\
\hline 1. & $\begin{array}{l}\text { Growing leguminous and } \\
\text { non-leguminous fodder }\end{array}$ & 92 & $\begin{array}{c}46 \\
(0.46)\end{array}$ & 10 & 94 & $\begin{array}{c}47 \\
(0.94)\end{array}$ & 1 & 14 & $\begin{array}{c}7 \\
(0.21)\end{array}$ & 3 & 1.61 & 1 \\
\hline 2. & Varieties grown & 181 & $\begin{array}{c}90.5 \\
(0.91)\end{array}$ & 4 & 17 & $\begin{array}{c}8.5 \\
(0.17)\end{array}$ & 7 & 2 & $\begin{array}{c}1 \\
(0.03)\end{array}$ & 7 & 1.11 & 7 \\
\hline 3. & $\begin{array}{l}\text { Fodder requirement and cropping } \\
\text { scheme preparation based on number } \\
\text { of animals }\end{array}$ & 114 & $\begin{array}{c}57 \\
(0.57)\end{array}$ & 9 & 70 & $\begin{array}{l}35 \\
(0.7)\end{array}$ & 2 & 16 & $\begin{array}{c}8 \\
(0.24)\end{array}$ & 2 & 1.51 & 3 \\
\hline 4. & Seed rate and sowing time & 157 & $\begin{array}{l}78.5 \\
(0.79)\end{array}$ & 5 & 36 & $\begin{array}{c}18 \\
(0.36)\end{array}$ & 6 & 7 & $\begin{array}{c}3.5 \\
(0.11)\end{array}$ & 5 & 1.25 & 6 \\
\hline 5. & $\begin{array}{l}\text { Importance of fodders for animal } \\
\text { health }\end{array}$ & 120 & $60(0.6)$ & 8 & 50 & $\begin{array}{l}25 \\
(0.5)\end{array}$ & 3 & 30 & $\begin{array}{c}15 \\
(0.45)\end{array}$ & 1 & 1.55 & 2 \\
\hline 6. & $\begin{array}{l}\text { Harvesting time and stages of green } \\
\text { fodder/grass }\end{array}$ & 146 & $\begin{array}{c}73 \\
(0.73)\end{array}$ & 6 & 44 & $\begin{array}{c}22 \\
(0.44)\end{array}$ & 5 & 10 & $\begin{array}{c}5 \\
(0.15)\end{array}$ & 4 & 1.32 & 4 \\
\hline 7. & $\begin{array}{l}\text { Post-harvest management of fodder/ } \\
\text { grass }\end{array}$ & 146 & $\begin{array}{c}73 \\
(0.73)\end{array}$ & 7 & 50 & $\begin{array}{l}25 \\
(0.5)\end{array}$ & 4 & 4 & $\begin{array}{c}2 \\
(0.06)\end{array}$ & 6 & 1.29 & 5 \\
\hline
\end{tabular}




\begin{tabular}{|c|c|c|c|c|c|c|c|c|c|c|c|c|}
\hline \multirow{3}{*}{$\begin{array}{l}\text { Sl. } \\
\text { No. }\end{array}$} & \multirow{3}{*}{ Item of adoption } & \multicolumn{11}{|c|}{ Adoption level } \\
\hline & & \multicolumn{3}{|c|}{ Poor } & \multicolumn{3}{|c|}{ Fair } & \multicolumn{3}{|c|}{ Good } & \multicolumn{2}{|c|}{ Average } \\
\hline & & $\mathrm{F}$ & $\%$ & Rank & $\mathrm{F}$ & $\%$ & Rank & $\mathrm{F}$ & $\%$ & Rank & Value & Rank \\
\hline 8. & $\begin{array}{l}\text { Silage making (importance, suitable } \\
\text { corps and making process) }\end{array}$ & 198 & $\begin{array}{c}99 \\
(0.99)\end{array}$ & 2 & 2 & $\begin{array}{c}1 \\
(0.02)\end{array}$ & 8 & 0 & $0(0)$ & 9 & 0 & 9 \\
\hline 9. & $\begin{array}{l}\text { Hay making (importance, suitable } \\
\text { corps and making process) }\end{array}$ & 196 & $\begin{array}{c}98 \\
(0.98)\end{array}$ & 3 & 2 & $\begin{array}{c}1 \\
(0.02)\end{array}$ & 9 & 2 & $\begin{array}{c}1 \\
(0.03)\end{array}$ & 8 & 1.03 & 8 \\
\hline 10. & $\begin{array}{l}\text { Value addition in straw with } 3-4 \% \\
\text { urea }+1 \% \text { mineral mixture }+50 \text { liter of } \\
\text { water in } 100 \mathrm{~kg} \text { dry fodder }\end{array}$ & 200 & $100(1)$ & 1 & 0 & $0(0)$ & 10 & 0 & $0(0)$ & 10 & 0 & 10 \\
\hline
\end{tabular}

F: Number of farmers agreed to that item; Figure in parenthesis shows value for an item

Table 4: Constraints in the adoption of fodder production and conservation technolgy $(\mathrm{N}=200)$

\begin{tabular}{ll}
\hline Sl. & Constraints \\
No. & \multicolumn{2}{c}{ Perception } & Rank \\
\cline { 1 - 2 }
\end{tabular}

A. Related to technology transfer

1. Unavailability/non-popularization of suitable fodder crops grown year round $\quad \begin{array}{llll}159 & 79.50 & 6\end{array}$

2. Fodder and grass production technology for degraded land

$140 \quad 70.00 \quad 7$

3. Fodder and grass production technology for problematic soil like alkaline, waste, desert $\quad \begin{array}{llll}167 & 83.50 & 5\end{array}$ area, etc.

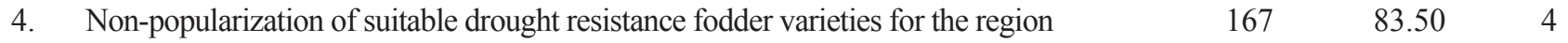

5. Non-popularization of fodder conservation techniques for value addition in fodder or straw $\quad \begin{array}{llll}173 & 86.50 & 3\end{array}$

6. Unavailability of fodder seeds suitable for the region $\quad \begin{array}{lll}180 & 90.00 & 2\end{array}$

7. No priority agenda/poor priority agenda of different technology transfer system regarding $\quad \begin{array}{llll}188 & 94.00 & 1\end{array}$ dissemination of fodder production and conservation technology

Sub-total/average

$167.71 \quad 83.85 \quad$ A

B. Related to accessibility

1. $\quad$ Poor purchasing power

$126.00 \quad 63.00 \quad 9$

Sub-total/average

$126.00 \quad 63.00 \quad$ B

C. Other unavoidable factors

1. Topography and soil type

$113 \quad 56.50 \quad 10$

2. Erratic rainfall

$139 \quad 69.50 \quad 8$

3. Poor availability of irrigation water

$170 \quad 85.00 \quad 4$

4. Social structure

$57 \quad 28.50 \quad 12$

5. Scarce resources

$102 \quad 51.00 \quad 11$

Total/average

$116.2 \quad 58.1 \quad \mathrm{C}$

3 categories. The first category-A is related to technology transfer. It has got 7 sub-points upon which the response were collected. The average of 167.71 farmers $(83.85 \%)$ responded about these constraints. 126 farmers (63\%) stated accessibility as the constraint under category-B.

Constraint category- $\mathrm{C}$ was other unavoidable factors related to socio-economic and geographical dimension. On the basis of rank obtained, regarding dissemination of fodder production and conservation, there was no technology transfer system having priority agenda (rank-I) with 94 percent followed by unavailability of fodder seeds suitable for tract, nonpopularization of fodder conservation techniques for value addition, non-popularization of suitable drought resistance fodder varieties for this region ranked II, III and IV, respectively. The extension agencies can play an important role to educate the farmers in adoption of improved production technologies for their benefits (Meena et al., 2006). The findings are akin to the observation of Singh et al. (2012) that high cost of feed 
ingredients posed as biggest constraint (rank-I) followed by constraints related to knowledge of feeding practices (rank-II).

But here the reality was different because there was no technology transfer system having priority agenda about fodder production and conservation in the study areas. Thus, the accessibility of farmers and other socio-economic (unavailable) factors were not showed more important than technology transfer issue. The constraints related to technology transfer were given first priority followed by constraints related to accessibility of farmers and other unavoidable factors.

\section{Conclusion}

The respondents had highest knowledge about leguminous and non-leguminous fodder followed by fodder requirement and cropping scheme preparation based on number of animals and importance of different roughages for animal health. The lowest adoption was found for the items for which there was the lowest knowledge level. The highest constraints were found related to technology transfer followed by constraints related to purchase. Thus, the study showed that if knowledge level was high the adoption level was also high. Therefore, farmers should be educated on improved fodder utilization practices and then the entrepreneurship should be developed so that he can access and adopt fodder production and conservation technology.

\section{References}

Kumar, V., 2009. Assessment of marketing charges and price spread under different channels in marketing of wheat.
Plant Archives 9(1), 171-172.

Manjunath, L.H., 2011. Need a space in eco-system. The Hindu Survey of Indian Agriculture, 27-28.

Meena, M.S., Prasad, M., Singh, R., 2006. Constraints perceived by rural agro-processors in adopting modern post-harvest technologies. Indian Research Journal of Extension Education 9(1), 1-5.

Rajput, B.P.S., Sahu, N.C., Kant, K., Kumar, R., 2012. Perceived training needs of dairy farmers regarding improved dairy farming practices and its relation with their socio-economic traits in Bundelkhand region. Indian Journal of Dairy Sciences 65(4), 342-347.

Rogers, E.M., 1995. Diffusion of Innovations. The Free Press, New York.

Sampath, K.T., Samanta, A.K., 2010. Minimizing potential risks by early warning strategy. The Hindu Survey of Indian Agriculture, 47-49.

Singh, M., Sharma, P., 2010. Forage production for livestock development: Problems, priorities and strategies. Extension Strategy for Bundelkhand Region, Zonal Project Directorate, Zone-IV(ICAR), Kanpur, 37-42.

Singh, A.S., Singh, K., Chakravarty, R., Viragar, V.G., Kumar, C., 2012. Constraints perceived by members of Manipur (India) milk producers' co-operative union in practicing improved dairy farming. Journal of Dairying, Food and Home Science 31(4), 279-283.

Tripathi, H., Maurya, R.K., 2013. Alternate feeding and fodder management practices followed by dairy farmers in Bundelkhand region of Uttar Pradesh. Animal Nutrition and Feed Technology 2013(13), 317-322. 